\title{
Environmental Impact Assessment of Household Consumption
}

Diana Ivanova, Konstantin Stadler, Kjartan Steen-Olsen, Richard Wood, Gibran Vita and Edgar G. Hertwich

Industrial Ecology Programme and Department of Energy and Process Engineering, Norwegian University of Science and Technology (NTNU), NO-7491 Trondheim, Norway

Pre-Print version of the manuscript.

The published version can be found here

http://onlinelibrary.wiley.com/doi/10.1111/jiec.12371/full

And should be cited as:

Ivanova, D., Stadler, K., Steen-Olsen, K., Wood, R., Vita, G., Tukker, A. and Hertwich, E. G. (2016), Environmental Impact Assessment of Household Consumption. Journal of Industrial Ecology, 20: 526-536. doi:10.1111/jiec.12371

\section{Summary}

We analyse the environmental impact of household consumption in terms of the material, water and land use requirements, as well as greenhouse gas (GHG) emissions, associated with the production and use of products and services consumed by these households. Using the new EXIOBASE 2.2 multi-regional input-output database, which describes the world economy at the detail of 43 countries, 5 rest-of-the-world regions and 200 product sectors, we are able to trace the origin of the products consumed by households and represent global supply chains in 2007. 
We highlight the importance of environmental pressure arising from households with their consumption contributing to more than $60 \%$ of global GHG emissions and between $50 \%$ and $80 \%$ of total land, material and water use. The footprints are unevenly distributed across regions with wealthier countries generating the most significant impacts per capita. Elasticities suggest a robust and significant relationship between households' expenditure and their environmental impacts, driven by a rising demand of non-primary consumption items. Mobility, shelter and food are the most important consumption categories across the environmental footprints. Globally, food accounts for $48 \%$ and $70 \%$ of household impacts on land and water resources respectively, with consumption of meat, dairy and processed food rising fast with income. Shelter and mobility stand out with high carbon and material intensity, whereas the significance of services for footprints relates to the large amount of household expenditure associated with them.

\section{Keywords:}

Household environmental impacts, footprint analysis, environmentally extended multiregional input-output (EE-MRIO) analysis, regression analysis, expenditure elasticity

\section{Address correspondence to:}

Diana Ivanova

Industrial Ecology Programme and Department of Energy and Process Engineering Sem Sælands vei 7

Norwegian University of Science and Technology (NTNU)

NO-7491 Trondheim, Norway

diana.n.ivanova@ntnu.no

www.ntnu.no/indecol 


\section{Introduction}

Scientists have investigated the resource use required to support household consumption in an effort to understand the relationship between humans and nature (Wackernagel and Rees 1996; Fischer-Kowalski et al. 2014; Herendeen and Tanaka 1976). They have investigated the emissions caused by the production, use and disposal of products in final use to target efforts to reduce environmental impacts and assess trade-offs (Dietz et al. 2009; Hertwich 2011; Tukker et al. 2010). Traditionally, the analysis of household environmental impacts was based on national statistics and production systems, treating imported goods as if they had been produced in the country where they are consumed (Lenzen et al. 2006; Hertwich 2011; Tukker and Jansen 2006). The energy and emissions intensities of products produced in different countries can be quite different, reflecting a combination of differences in the structure and efficiency of economies and in the product mix being produced. Including the technology of important trade partners as proxies for imports to Norway, Peters and Hertwich (2006) demonstrated a striking impact of technology differences: the foreign production of products consumed by Norwegian households accounted for 13 million tons $\mathrm{CO}_{2}$, whereas using domestic production as a proxy would give only 5 million tons. Weber and Matthews (2008) found significant effects also for the United States, which is less trade exposed. As a result, global multi-regional input-output models were developed to trace the environmental impacts associated with consumption. Hertwich and Peters (2009) provided the first analysis of the carbon footprint of different nations, identifying the role of households, public consumption and investments, and specifying the role of different consumption categories as a function of income. These calculations have been reproduced and updated (Davis and Caldeira 2010) and extended to other pollutants, materials, land use, and water consumption (Wiedmann et al. 2013; Kanemoto et al. 2014; Steen-Olsen et al. 2012). In recent work, 
however, consumption is addressed more broadly, not focusing on understanding households but rather looking at entire nations.

In this article, we analyse the environmental impact of household consumption of different countries in terms of the material, water and land use requirements, as well as greenhouse gas emissions, associated with the production and use of products and services consumed by these households. We do so using the newly established EXIOBASE 2.2 multi-regional inputoutput database, which describes the world economy in 2007 consisting of 43 countries, 5 rest-of-the-world (RoW) regions and 200 product sectors (Wood et al. 2015). The land footprint reported here is an unweighted land use as opposed to the productivity weighting applied by Wackernagel and Rees (1996). The other indicators are water footprint (Hoekstra 2003), carbon footprint (Wiedmann and Minx 2008) and material footprint (Wiedmann et al. 2010). The concept of footprint family has been tested against criteria such as policy relevance, indicator coverage and their complementary properties (Galli et al. 2012).

The motivation behind the recent focus on national footprints is the importance of emissions embodied in international trade to climate policy (Wyckoff and Roop 1994; Munksgaard and Pedersen 2001; Peters and Hertwich 2008). Time series of national carbon footprints show that increasing imports from developing countries have contributed significantly to the continued rise of the national carbon footprint of developed countries, even though many of these countries have managed to stabilize and even reduce their territorial greenhouse gas emissions (Kanemoto et al. 2014; Peters et al. 2011). While the national focus is appropriate for national and international policy making, an understanding of household footprints can provide insights into the social determinants of environmental impacts and can inform household actions directed towards reducing footprints. Household consumption has a strong relation with consumer behavior, lifestyles and daily routines and a potential resistance to change due to social and cultural embeddedness (Caeiro et al. 2012). 
Households have a relatively large degree of control over their consumption, but they often lack accurate and actionable information on how to improve their own environmental performance (Gardner and Stern 2008), and household footprint calculations can provide such information.

The novelty of our study is that it uses an integrated methodological framework across the set of footprint indicators to evaluate household environmental performance based on a database with a higher level of environmental detail. This integrative approach allows us to assess and compare environmental impacts of household consumption across indicators, regions and consumption categories directly and with lower uncertainty. It can further be used to identify where mitigation of certain impacts, for example, emission reductions, would come at the expense of other impact categories such as higher levels of water, land and material consumption (Tukker et al. 2013).

\section{Methods and Data}

Household environmental impacts are derived from an environmentally extended multiregional input-output (EE-MRIO) model constructed using the high-resolution EXIOBASE database (Wood et al. 2015). The core of the model is an input-output table representing the flow of goods and services throughout the global economy for the reference year 2007. All emissions and resources required for the production of output are allocated to goods and services purchased by final consumers (Hertwich 2011).

The analysis is based on version 2.2 of EXIOBASE, which features a higher level of detail on environmentally relevant sectors (e.g. agriculture, energy, manufacturing) and environmental extensions (e.g. emissions, resource use and pollutants) in comparison to other MRIO databases (Wood et al. 2015). EXIOBASE has a major advantage in providing much greater product disaggregation (200 product sectors) in an integrated framework within the 
System of Environmental-Economic Accounting (SEEA) guidelines. It accommodates information about 43 countries which together account for about $89 \%$ of global GDP and between $80 \%$ and $90 \%$ of the trade flow by value within Europe (Stadler et al. 2014). The multi-regional input-output table is supplemented with information on the environmental load intensities of economic sectors. Economic accounts were coupled with data on resource use and emissions sourced from databases with information on primary resource extractions, emission factors and activity variables, agricultural and forestry activities (Food and Agriculture Organization of the United Nations Statistics Division (FAOSTAT), the International Energy Agency (IEA) database etc.) (Tukker et al. 2013).

The global warming potential (GWP) metric is used to convert greenhouse gases $\left(\mathrm{CO}_{2}\right.$, $\mathrm{CH}_{4}, \mathrm{~N}_{2} \mathrm{O}$ and $\mathrm{SF}_{6}$ ) to equivalent amounts of $\mathrm{CO}_{2}$ by weighting their radiative properties for a time horizon of 100 years. Land use reflects use of cropland, pasture land and forest land. The material footprint relocates the domestic extraction of raw materials (primary crops, crop residues, fodder crops, grazing, wood, aquatic animals, metal ores, non-metallic minerals and fossil fuels) from production to consumption in a mutually exclusive way, including only materials that are directly used by an economy. Our water footprint indicator includes blue (fresh surface and groundwater) water consumption embodied in agriculture and livestock products, manufactured products, electricity and direct demand from households. The national environmental footprint is calculated as a function of the footprint multiplier, capturing the intensity of household purchases (e.g. amount of GHG emissions per EUR of household expenditure), and the product quantity demanded in monetary terms.

Following the convention of national accounts, final demand is the estimate obtained by summing household, non-profit organization and government spending as well as capital formation and changes in inventories and valuables in a given year (SNA 2008). In order to isolate the environmental impacts of households, we only take into account household 
expenditure across product sectors. This approach allows us to estimate the magnitude of indirect GHG emissions and resource use embodied in the global supply chains of household purchases subject to certain limitations discussed later.

In addition, households generate environmental stress directly through their use of some products, for example, when driving or using fuel to heat their homes. In EXIOBASE, household direct impacts are aggregated into a total for each region. We distribute direct carbon emissions between personal transport and residential fuel use following the GTAP 7 database (Lee 2008). We roughly allocated $\mathrm{CO}_{2}$ emissions from coal, crude oil and gas to housing (i.e. shelter) and those from petroleum products to transport. Direct water use was allocated to shelter under the consideration of prior observations, see Vewin (2012), Vickers (2001) and EEA (2001). Direct non-commercial use of land and materials by households was neglected.

Finally, by applying the concept of expenditure elasticity, we are able to evaluate changes in the environmental footprints due to changes in household expenditure (Baiocchi et al. 2010; Kerkhof et al. 2009; Weber and Matthews 2008). Household expenditure elasticity, $\varepsilon$, measures the percentage change in the quantity of environmental impacts with respect to a $1 \%$ rise in the total household demand (measured in monetary units):

$$
\varepsilon_{i}=\left(\partial f_{i} / \partial y\right) /\left(f_{i} / y\right)
$$

where $y$ represents per capita yearly expenditure and $f$ represents per capita footprint for each of the footprint indicators $i$. Model (1) can be transformed using natural logarithm transformation resulting in a set of univariate regressions for each footprint indicator, where $a$ and $\varepsilon$ are constants and $u$ is the error term:

$$
\ln f_{i}=a_{i}+\varepsilon_{i} \ln y+u_{i}
$$




\section{Results}

\section{Carbon Footprint}

The global carbon footprint associated with household consumption in 2007 was $22 \mathrm{Gt}$ $\mathrm{CO}_{2}$-eq including direct impacts and impacts embodied in household purchases. This amounts to $65 \%$ of the total emissions generated that year. The average allocation of environmental impacts across final demand categories is presented in table 1 . GHG emissions were unevenly distributed across regions with households in four major economies, namely, the United States, China, Japan and Russia, contributing to roughly half of the global impacts from household consumption. Households in the United States alone contributed to a quarter of global emissions, or 5.6 Gt $\mathrm{CO}_{2}$-eq. The most significant contribution is from the consumption of energy-intensive services and electricity produced from coal. The household

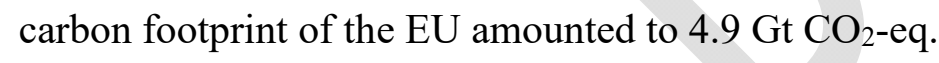

On a per-capita basis, carbon footprints of households vary widely (figure 1). The United States contributes to $18.6 \mathrm{t} \mathrm{CO} 2$-eq/cap. The world average is $3.4 \mathrm{t} \mathrm{CO} 2$-eq/cap, suggesting a 5.5 factor difference. In terms of the total final demand, the United States contributes to 4.9 times higher GHG emissions than the world average from a consumption perspective and to only 3.9 times higher emissions from a production perspective. Thus, the United States are a net importer of GHG embodied in traded goods, largely due to household consumption.

A strong positive correlation between GDP per capita based on purchasing power parity (PPP) and per capita carbon footprints is signaled by the correlation coefficient of 0.87 . Several Western economies such as Sweden $\left(8.7 \mathrm{t} \mathrm{CO}_{2}\right.$-eq/cap), France $\left(8.8 \mathrm{t} \mathrm{CO}_{2}\right.$-eq/cap) and Japan (9.0 $\mathrm{t} \mathrm{CO}_{2}$-eq/cap) stand out with lower impacts than countries with similar income related to the prevalence of nuclear and hydro power (EEA 2013). Hence, a significant portion of household impacts from Sweden and France are embodied in imports, 65\% and 
$51 \%$ respectively (figure 2), due to their higher carbon intensity compared to domestic production.

The distribution of GHG emissions from household activity on domestic goods and imports varies largely across countries. Luxembourg stands out with a low share of domestic indirect emissions, about $1.4 \mathrm{t} \mathrm{CO}_{2}$-eq/cap in 2007 or $8 \%$ of the country's carbon footprint (figure 2). China, on the other hand, relies strongly on domestic production to satisfy local household demand, with indirect domestic impacts accounting for $92 \%$ of the country's total footprint. Moreover, Chinese households have much lower relevance for the national carbon footprint compared to the rest of the sample with local environmental pressure being driven by capital requirements. Finally, Russia has the highest amount of emissions embodied in exports with the most carbon-intensive sector being petroleum products.

Table 1. Environmental impact by final demand category.

The mean and standard deviation estimates respond to the sample of 43 countries included in the EXIOBASE with the deviation caused by the different distribution of final demand categories across countries. Environmentally-relevant requirements are linked to final demand by Households, Non-Profit Institutions Serving Households (NPISH), Governments, Gross Capital Formation and Changes in Inventories. Changes in inventories occur when prices prevailing when goods are withdrawn differ from prices when production takes place (SNA 2008).

\begin{tabular}{|c|c|c|c|c|}
\hline & Carbon footprint & Land footprint & Material footprint & Water footprint \\
\hline Households & $65 \pm 7 \%$ & $70 \pm 11 \%$ & $51 \pm 8 \%$ & $81 \pm 7 \%$ \\
\hline NPISH & $1 \pm 1 \%$ & $1 \pm 1 \%$ & $1 \pm 1 \%$ & $1 \pm 1 \%$ \\
\hline Governments & $7 \pm 3 \%$ & $5 \pm 3 \%$ & $7 \pm 3 \%$ & $5 \pm 3 \%$ \\
\hline Gross Capital Formation & $24 \pm 7 \%$ & $19 \pm 10 \%$ & $37 \pm 9 \%$ & $10 \pm 6 \%$ \\
\hline Changes in Inventories & $3 \pm 2 \%$ & $5 \pm 5 \%$ & $4 \pm 3 \%$ & $3 \pm 2 \%$ \\
\hline
\end{tabular}


Households emitted $4.4 \mathrm{Gt} \mathrm{CO}_{2}$-eq directly through activities involving combustion of fuel amounting to roughly $20 \%$ of global GHG emissions from household activity. On average, direct carbon emissions originate from the use of transport (73\%) and household fuel $(27 \%)$. The share of direct GHG emissions is largest for households in France and Belgium, more than $28 \%$. The larger fraction of carbon impacts occurs in the form of emissions embodied in purchases, as opposed to direct impacts. On a global scale, GHG emissions embodied in household purchases are driven by consumption of services $(27 \%)$, shelter $(25 \%)$, manufactured products (17\%), mobility (15\%) and food (13\%).

Figure 3 presents an analysis of the carbon intensity of different consumption categories of EU households. Mobility has the highest amount of emissions per unit of household expenditure within the European Union, $3.4 \mathrm{~kg} \mathrm{CO}$-eq/EUR (figure 3). Through driving own vehicles, EU households emit roughly half of the GHG emissions related to mobility directly, a total of $0.7 \mathrm{Gt} \mathrm{CO}_{2}$-eq. The remaining mobility-related emissions are indirect emissions, in particular, consumption of gasoline and diesel $\left(0.4 \mathrm{Gt} \mathrm{CO}_{2}\right.$-eq) and motor vehicles $(0.2 \mathrm{Gt}$ $\mathrm{CO}_{2}$-eq). Shelter is similarly significant for the carbon footprint of $\mathrm{EU}$ households, comprising $26 \%$ of their impacts. This consumption category has a lower carbon intensity, 0.9 $\mathrm{kg} \mathrm{CO}$-eq/EUR, though it is associated with higher share of household expenditure. Out of the six consumption categories, services are least carbon-intensive; however, $45 \%$ of household expenditure is directed towards consumption of services, hence, the category's contribution of $17 \%$ from the total carbon impacts within EU.

\section{Land Footprint}

Almost 65 million $\mathrm{km}^{2}$ of global land use was required to meet household demand in 2007. As a result, roughly $70 \%$ of the global land use was embodied in household purchases with the ratio reaching up to $94 \%$ for Russia and South Africa. Other countries with developed resource-intensive forestry sectors such as Canada and Finland rely strongly on wood 
products for domestic construction and investments, hence, their lower relative importance of households (figure 2).

Together, the purchases of households in Russia, China, the United States, Brazil and Australia account for more than 48\% (31 million $\left.\mathrm{km}^{2}\right)$ of total land resources embodied in household consumption in 2007. The EU contributed 15\% (9.6 million $\left.\mathrm{km}^{2}\right)$. GDP correlates weakly with household land requirements with a correlation coefficient of 0.38 . Australia has the most extensive per capita land footprint, $0.16 \mathrm{~km}^{2} /$ cap, more than 16 times higher than the global average of $0.01 \mathrm{~km}^{2} / \mathrm{cap}$. Russia has the second largest impact per capita at 0.07 $\mathrm{km}^{2} / \mathrm{cap}$. The two countries are also the ones with the highest share of household impacts embodied in domestic production, equivalent to more than $93 \%$ of the land use. Australian land use is embodied in household purchases of food products, whereas shelter requirements dominate the land footprint of Russian households. Other forestry-rich countries such as Norway and Finland similarly have a significant portion of land use linked to purchases of wood and other forestry products.

Smaller EU economies face geographical restrictions and limited resources encouraging them to satisfy a larger share of household demand through imports from the developing world. As depicted on figure 2, households in Luxembourg, the Netherlands, and Belgium give rise to the highest land footprint per capita within the EU, although only a negligible fraction of that reflects domestic land use, between $1 \%$ and $3 \%$. A significant share of the land impacts of the countries is due to imports of crops and seeds from Brazil, China and the United States. The Netherlands, for example, relies strongly on imported feed for its developed livestock industry (Tukker et al. 2014).

On a global scale, $46 \%$ of the land use occurs to meet household demand for food followed by shelter and services contributing $26 \%$ and $15 \%$ respectively. Food has the largest land 
multiplier within the EU, $7.2 \mathrm{~m}^{2}$ per EUR spent on food. Household consumption of nonclassified food items entails a significant fraction of resource use across EU countries, about $2.6 \mathrm{~km}^{2}$. Clothing is the second most land-intensive consumption categories (figure 3 ), though it is associated with only four percent of the land use by EU households. Mobility is the least land-intensive consumption category requiring $0.5 \mathrm{~m}^{2} /$ EUR. Area covered by roads and other transportation infrastructure are not included in the estimate.

\section{Material Footprint}

The global material footprint of households amounted to $32 \mathrm{Gt}$ in 2007, which is equivalent to $48 \%$ of the total raw materials that were extracted and used that year (table 1 ). Two-fifths of the total material use fulfils consumption requirements of households in the United States, China, India and Brazil. In 2007, households from the United States alone contributed to the largest material footprint in absolute values, $5.5 \mathrm{Gt}$ or $17 \%$ of the global material impacts. More than a quarter of this amount was used to enable local consumption of products of meat cattle, processed food, and hotel and restaurant services. In comparison, the EU has a household material footprint of $7.1 \mathrm{Gt}$.

On a per capita basis, Luxembourg and Australia stand out with high levels of material footprint, $27.6 \mathrm{t} / \mathrm{cap}$ and $26.3 \mathrm{t} / \mathrm{cap}$ respectively. Other developed economies show similar levels of household material impacts, hence, the correlation of 0.87 between national gross domestic product and material footprint. In comparison, the global average amounts to 4.9 t/cap. Across the selected 43 countries, India has the lowest value of material impacts per capita, 2 t/cap.

Forty percent of global household material impacts $(13 \mathrm{Gt})$ can be linked to internationally traded commodities across the 43 countries and 5 RoW regions. For Luxembourg, only two percent of the material footprint results from domestic extraction of materials, equivalent to a 
total of $0.2 \mathrm{Mt}$ in 2007 . The rest of the material footprint, a total of $13 \mathrm{Mt}$, can be linked to household consumption of foreign products with highest environmental impacts embodied in imports of raw materials (e.g. crude oil, sand and clay) from Russia and China and chemicals (e.g. fertilizers) from India.

In the case of Australia, 58\% of households' total material footprint in 2007, about 322 million tons, is linked to extraction of raw materials from the domestic natural environment. The material footprint embodied in imports is dominated by industrial materials (e.g. sand and clay, coal) from China. Norway has the third largest material footprint per capita. More than three fourths of the embodied material impacts relate to foreign extraction, especially imports from China and Russia. The country is a net exporter of materials such as stone and crude oil.

Globally, $36 \%$ of the material footprint arising from household activity can be attributed to food consumption, followed by services $(23 \%)$ and manufactured products $(17 \%)$. A comparison of the material intensities of consumption categories in the EU (figure 3) shows food to have the highest material multiplier with $2.8 \mathrm{~kg}$ of extracted materials embodied per EUR. More than 11\% of EU households' material footprint is embodied in consumption of processed food and dairy products $(0.8 \mathrm{Gt})$. Consumption of manufactured products is the second largest contributor to the material footprint of EU households with $20 \%$ (1.8 kg/EUR).

\section{Water Footprint}

In 2007 , the global blue water footprint associated with household consumption is 1,386 $\mathrm{km}^{3}$. Thus, households accounted for $81 \%$ of the total use of fresh water resources, followed by fixed capital formation (10\%) and demand from governments (5\%).

A total of $670 \mathrm{~km}^{3}$ or $48 \%$ of global water impacts is embodied in household activity from India, United States and China. The per capita footprint is smallest in Indonesia with 82 $\mathrm{m}^{3} /$ cap and largest in Luxembourg with $820 \mathrm{~m}^{3} /$ cap with a global average of $210 \mathrm{~m}^{3} / \mathrm{cap}$. 
Again, the GDP level correlates positively with household freshwater use, with a coefficient of 0.74 . Our choice of environmental indicator, however, could potentially influence the findings. Blue water consumption does not take into account the variation of crop water needs due to the climate with dry warm climates such as Spain requiring much irrigation (SteenOlsen et al. 2012).

On average, less than $5 \%$ of total household water footprint is in the form of direct consumption of water resources. Russia, Canada, the US and Norway stand out among the countries with the largest per capita direct water use by households ranging between 28 and $25 \mathrm{~m}^{3}$ per capita. With regards to water use embodied in global supply chains, consumption of agriculture and livestock products required a total of $975 \mathrm{~km}^{3}$ of water resources, or $74 \%$ of the indirect water footprint. The second largest contributor to blue water footprint is the services sector demanding about $18 \%$ of global household footprint. South Korea has the largest contribution of services to water use: $34 \%$ of the total footprint or $5.3 \mathrm{~km}^{3}$. Hotel and restaurant services have the highest water intensity. Water footprint multipliers are ranked similar to the land footprint multipliers within the EU, with food being most intensive $(0.17$ $\mathrm{m}^{3} /$ EUR $)$, followed by clothing $\left(0.05 \mathrm{~m}^{3} /\right.$ EUR $)$ and manufactured products $\left(0.02 \mathrm{~m}^{3} / \mathrm{EUR}\right)$.

About $27 \%$ of household water footprint was embodied in imports $\left(370 \mathrm{~km}^{3}\right)$. Luxembourg has the highest fraction of impacts embodied in imports amounting to $99 \%$ with high importance of food imports such as seeds, grains, vegetables and fruits. Greece has the second highest per capita footprint, about $700 \mathrm{~m}^{3}$, which is relatively equally distributed across domestic extraction (57\%) and imports (41\%) of indirect water resources with the latter largely linked to food and agricultural products. Emerging economies such as the BRIC countries are self-sustained when it comes to their water consumption. 


\begin{tabular}{|c|c|c|c|c|}
\hline Countries & Carbon Footprint (tCO2e) & Land Footprint $\left(1000 \mathrm{~m}^{2}\right)$ & Material Footprint (t) & Water Footprint $\left(\mathrm{m}^{3}\right)$ \\
\hline World average & 3.4 & 10.0 & 4.9 & 209 \\
\hline Austria & 11.3 & 18.1 & 17.4 & 298 \\
\hline Belgium & 12.2 & 28.1 & 17.8 & 492 \\
\hline Bulgaria & 5.4 & 6.9 & 8.1 & 182 \\
\hline Cyprus & 10.9 & 9.2 & 12.4 & 278 \\
\hline Czech Republic & 9.4 & 9.2 & 11.8 & 174 \\
\hline Germany & 11.9 & 20.0 & 16.0 & 347 \\
\hline Denmark & 12.2 & 20.9 & 16.8 & 453 \\
\hline Estonia & 10.9 & 20.9 & 15.6 & 258 \\
\hline Spain & 8.1 & 21.0 & 14.2 & 561 \\
\hline Finland & 13.6 & 27.4 & 17.9 & 304 \\
\hline France & 8.8 & 22.3 & 14.2 & 396 \\
\hline Greece & 13.4 & 26.9 & 18.3 & 700 \\
\hline Hungary & 5.9 & 8.2 & 7.3 & 194 \\
\hline Ireland & 12.9 & 22.1 & 17.1 & 297 \\
\hline Italy & 9.6 & 19.1 & 13.6 & 407 \\
\hline Lithuania & 6.5 & 12.5 & 9.1 & 180 \\
\hline Luxembourg & 18.5 & 44.4 & 27.6 & 816 \\
\hline Latvia & 6.2 & 22.9 & 10.8 & 181 \\
\hline Malta & 9.2 & 14.9 & 14.8 & 628 \\
\hline Netherlands & 11.8 & 35.5 & 17.2 & 575 \\
\hline Poland & 7.8 & 9.2 & 10.3 & 130 \\
\hline Portugal & 6.8 & 18.0 & 11.5 & 509 \\
\hline Romania & 4.6 & 9.4 & 12.2 & 325 \\
\hline Sweden & 8.7 & 18.8 & 15.7 & 322 \\
\hline Slovenia & 10.1 & 20.2 & 13.4 & 262 \\
\hline Slovakia & 8.3 & 14.5 & 11.9 & 287 \\
\hline United Kingdom & 13.3 & 21.9 & 17.9 & 456 \\
\hline United States & 18.6 & 23.0 & 18.4 & 651 \\
\hline Japan & 9.0 & 11.2 & 9.2 & 290 \\
\hline China & 1.8 & 5.4 & 3.1 & 130 \\
\hline Canada & 14.6 & 40.6 & 18.1 & 510 \\
\hline South Korea & 8.7 & 13.8 & 10.4 & 340 \\
\hline Brazil & 1.8 & 22.0 & 8.2 & 159 \\
\hline India & 0.8 & 2.1 & 2.0 & 261 \\
\hline Mexico & 3.8 & 16.6 & 5.9 & 277 \\
\hline Russia & 7.6 & 69.6 & 9.3 & 331 \\
\hline Australia & 17.7 & 160.8 & 26.3 & 660 \\
\hline Switzerland & 11.3 & 26.5 & 15.7 & 396 \\
\hline Turkey & 4.7 & 13.0 & 7.7 & 388 \\
\hline Taiwan & 8.6 & 9.2 & 7.7 & 308 \\
\hline Norway & 10.3 & 37.2 & 18.6 & 474 \\
\hline Indonesia & $1.3 \mid$ & 2.6 & 2.7 & 81.5 \\
\hline South Africa & 5.5 & 21.5 & 6.6 & 165 \\
\hline
\end{tabular}

Figure 1: Environmental footprints of household consumption across countries.

The figure includes the world average and 43 selected countries from EXIOBASE, ordered alphabetically by country codes. The world average includes all 43 countries and the 5 rest-ofthe-world regions. 

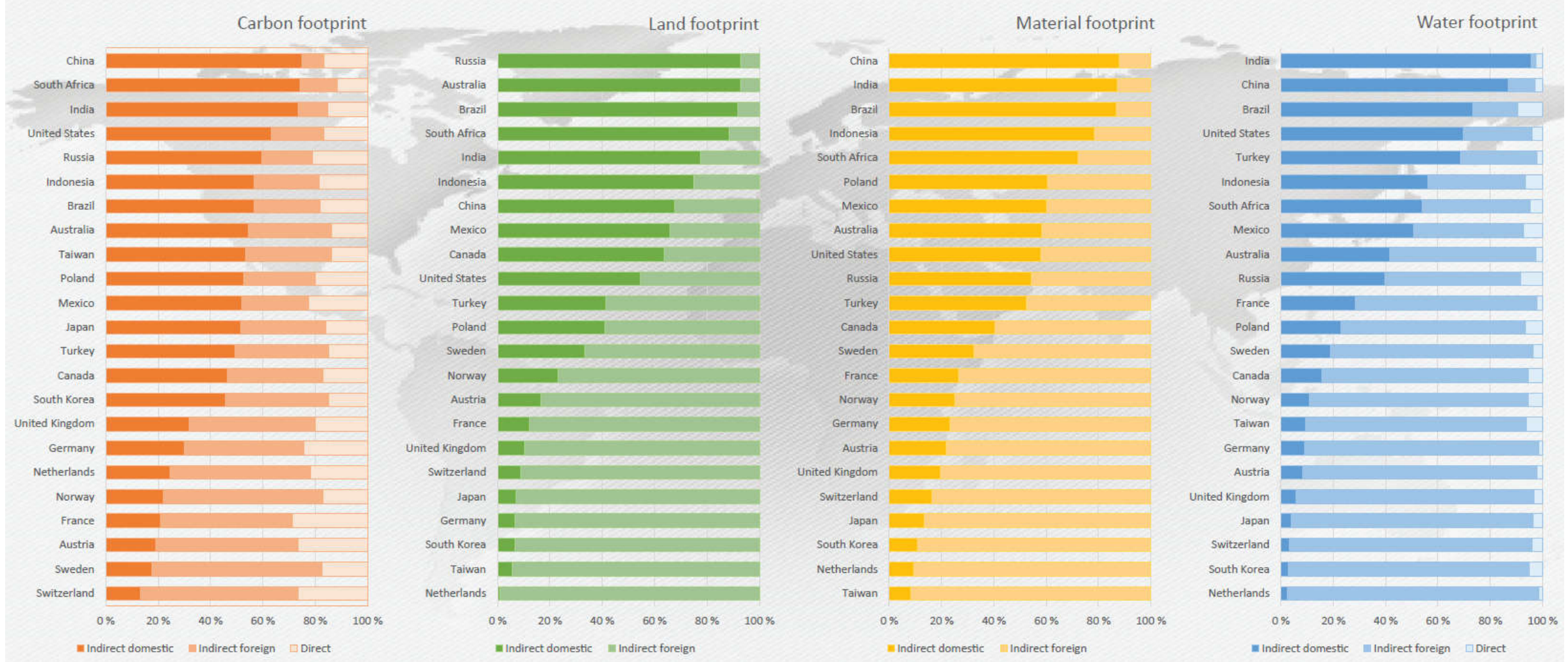

Figure 2: Indirect versus direct environmental impacts of household consumption across 23 selected countries.

The figure separates household consumption footprint on direct (pressures that are emitted directly by consumption activities), indirect domestic (embodied in domestically produced products and services) and indirect foreign (embodied in imported products and services) across selected countries available in EXIOBASE. Households are not accountable for direct environmental impacts in relation to land and material use in EXIOBASE. Countries have been ordered by their share of indirect domestic impacts. Check the Supplementary Material for an overview of all 43 countries. 


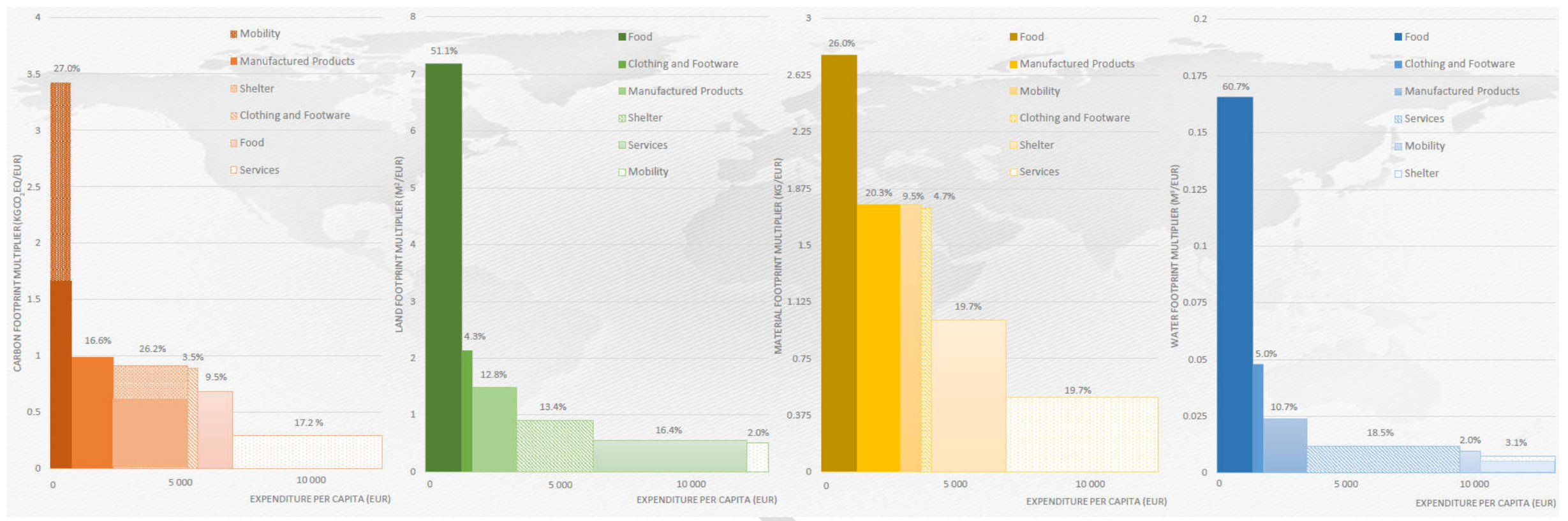

Figure 3: Contribution of consumption categories to the carbon, land, material and water footprint of EU households.

The contribution of consumption categories to the total environmental footprints can be split into two parts: the quantity of products within the category bought, measured by expenditure per capita in EUR, and the footprint intensities measured by footprint multipliers - the environmental impact per EUR of expenditure in the category. Consumption categories in the legend have been ordered by their environmental intensity (by magnitude of multipliers). The footprint multipliers are measured in $\mathrm{kg} \mathrm{CO}_{2}$-eq/EUR for carbon, $\mathrm{m}^{2} / \mathrm{EUR}$ for land, $\mathrm{kg} / \mathrm{EUR}$ for material and $\mathrm{m}^{3}$ /EUR for water. The percentage labels describe the share of a category's footprint from the total footprint of household consumption within EU. The lighter shaded parts of 'Shelter' and 'Mobility' columns denote direct GHG emissions and water use by households. Check the Supplementary information for a breakdown of countries' footprint across consumption categories. 
Table 2: Elasticity of footprints with respect to total household expenditure, by footprint and consumption category.

Expenditure elasticity of consumption measures the effect of changes in per capita expenditure on the environmental footprints. The 'Total' row shows the estimated coefficients when using the total per capita footprints as dependent variables that are regressed on household expenditure per capita. To compare coefficients across consumption categories, additional regressions are run separately where dependent variables are the environmental footprints of the different categories. The land and material footprints are associated with no direct impacts by households. The symbols $*, * *$ and $* * *$ denote significance levels, $\alpha$, of $10 \%, 5 \%$ and $1 \%$ respectively.

\begin{tabular}{|c|c|c|c|c|c|c|c|c|}
\hline & \multicolumn{2}{|c|}{ Carbon footprint } & \multicolumn{2}{|c|}{ Land footprint } & \multicolumn{2}{|c|}{ Material footprint } & \multicolumn{2}{|c|}{ Water footprint } \\
\hline & $\varepsilon$ & $\mathrm{R}^{2}$ & $\varepsilon$ & $\mathrm{R}^{2}$ & $\varepsilon$ & $\mathrm{R}^{2}$ & $\varepsilon$ & $\mathrm{R}^{2}$ \\
\hline Total & $0.66^{* * *}$ & 0.83 & $0.56^{* * *}$ & 0.49 & & 0.85 & $0.40^{* * *}$ & 0.54 \\
\hline \multicolumn{9}{|l|}{ Direct impact } \\
\hline Shelter & $0.70^{*}$ & 0.08 & - & - & & - & $0.20^{*}$ & 0.07 \\
\hline Mobility & $0.80^{* * *}$ & 0.83 & - & - & & - & - & - \\
\hline \multicolumn{9}{|l|}{ Indirect impact } \\
\hline Shelter & $0.58^{* * *}$ & 0.44 & $0.45^{* *}$ & 0.20 & $0.73^{* * *}$ & 0.54 & $0.75^{* * *}$ & 0.60 \\
\hline Food & $0.41^{* * *}$ & 0.62 & $0.49 * * *$ & 0.41 & $0.29 * * *$ & 0.46 & $0.30^{* * *}$ & 0.35 \\
\hline Clothing & $0.58^{* * *}$ & 0.63 & $0.76^{* * *}$ & 0.65 & $0.63^{* * *}$ & 0.62 & $0.67^{* * *}$ & 0.62 \\
\hline Mobility & $0.77 * * *$ & 0.79 & $0.80^{* * *}$ & 0.68 & $0.76^{* * *}$ & 0.81 & $0.54 * * *$ & 0.38 \\
\hline Manufactured products & $0.75^{* * *}$ & 0.86 & $0.88^{* * *}$ & 0.69 & $0.75^{* * *}$ & 0.87 & $0.72 * * *$ & 0.77 \\
\hline Services & $0.75^{* * *}$ & 0.81 & $0.91^{* * *}$ & 0.69 & $0.71^{* * *}$ & 0.81 & $0.69^{* * *}$ & 0.51 \\
\hline
\end{tabular}

The environmental impacts of household consumption are strongly correlated with consumer expenditure as listed in table 2 . The expenditure elasticity of carbon is positive and significant at the $1 \%$ level meaning that as household income levels rise, the carbon footprint increases by $66 \%$ for each doubling of household spending. The land and water footprint further have a positive statistical association with household expenditure, though differences in the expenditure variable explain much lower fraction of the variation of the resource use across countries. Elasticity of food and shelter have the lowest $\mathrm{R}^{2}$, likely reflecting the relevance of other determinants of land and water use such as natural resource availability and other geographical conditions (Hertwich and Peters 2009). A further break-down of expenditure elasticities on a sectoral level shows that environmental impacts from staple food 
purchases (e.g. wheat, cereal grains, seeds and non-classified crops) do not increase significantly with household expenditure, unlike the footprint of dairy and meat products.

The share of emissions and resources use for production of non-primary consumption items such as some services, manufactured products and clothing consumed by households is much smaller in emerging economies and strongly driven by rising levels of disposable income and expenditure. This is reflected in the higher elasticities coefficients of those consumption categories across the footprint indicators (table 2).

\section{Discussion and Conclusions}

This study provides a comprehensive insight into the global environmental impacts by households. It highlights the significance of environmental pressure arising from households with their consumption giving rise to more than $60 \%$ of global GHG emissions and between $50 \%$ and $80 \%$ of total resource use. A significant portion of the emissions and resource use are embodied in internationally traded commodities.

The regression analysis introduces household expenditure as a positive and highly significant determinant of household environmental impacts with an elasticity coefficient varying between 0.40 for water and 0.66 for carbon. National income is also positively correlated with the footprints, which is consistent with our expectations that higher disposable income of households reflects more purchases of products, hence, higher levels of embodied impacts. The correlation coefficient describing the relationship between GDP and household land use is smaller than the coefficients regarding the other footprints suggesting the importance of other factors for the variation of land use. For example, prior studies have investigated the influence of resource availability on the national land use footprints (Wiedmann et al. 2013; Weinzettel et al. 2013). We also find the largest consumers of land, Russia (forest land) and Australia (arable and pasture land), to have the highest share of 
domestic land impacts, suggesting that households tend to consume more resources when they are readily available. It should be noted that our land indicator currently does not capture any potential differences in the land's fertility across countries; how the choice of indicator affects results should be investigated further.

We confirm earlier conclusions about mobility, shelter and food being the most important consumption categories (Hertwich and Peters 2009). Though their environmental relevance varies across footprint indicators, the three categories consistently make up between $55 \%$ and $65 \%$ of the total impacts. Food has the highest land, material and water multipliers, hence, switching a EUR of expenditure from food to clothing in the EU, for example, results in a reduction of $5.1 \mathrm{~m}^{2}$ of land resources, $1.0 \mathrm{~kg}$ of extracted materials and $0.1 \mathrm{~m}^{3}$ of fresh water. At the same time, any redirecting expenditure from the food category to any other but services would cause increases in GHG emissions. This brings attention to an important implication for any policy targeting reductions of household footprints in absolute terms, particularly, what is the environmental opportunity cost of reducing impacts in a certain category. Conversely, a redirection of household expenditure towards less resource intensive services is more straightforward as it results in impact reduction across all footprint indicators. Nevertheless, one should always regard a certain degree of non-substitutability of consumption items and categories in the re-design of household expenditure patterns.

Furthermore, GHG emissions and resource use from food consumption rise with income, though at a lower rate than non-primary consumption categories. The result is mainly driven by rising importance of dairy and meat products, processed food and tobacco products at high household expenditure. The large footprints of non-classified food items necessitate further investigation. 
Mobility has the largest carbon footprint in the EU, with household impact roughly evenly distributed between direct tailpipe emissions from driving private cars and emissions embodied in purchases of fuel, transport services and vehicles. The magnitude of direct emissions is also strongly determined by total household expenditure with a doubling of the total expenditures resulting in an $80 \%$ rise of direct transport emissions. The results draw attention to potential limitations of policy measures to reduce GHG emissions related to transportation. For starters, if the sole effect of rising purchasing power on mobility demand was to switch to more fuel-efficient vehicles, we would have found a negative coefficient on direct emissions. Instead, our results can be explained by other effects taking place as well. For instance, low-income households are generally characterized by lower car ownership rates, hence, they are more likely to resort to low-carbon alternatives such as public transportation and cycling (Steen-Olsen et al. 2014). Furthermore, the more efficient use of own vehicles potentially gives rise to rebound effects that could be direct (driving more due to increased affordability of fuel) and indirect (switching purchasing power to other goods). Nevertheless, we show that mobility has the largest carbon multiplier in EU context, according to which a redirection of one Euro of household expenditure to the second most carbon-intensive category, manufactured products, would result in a carbon cut of $2.4 \mathrm{~kg}$ $\mathrm{CO}_{2}$-eq. This is rather encouraging for residential GHG mitigation programs, especially in areas with high motor vehicle emissions.

In 2007 , shelter, more particularly the consumption of electricity, wood products, housing fuel and real estate services, contributed to $26 \%$ of the carbon, $13 \%$ of the land and $20 \%$ of the material footprints within EU, with average impact intensity relative to other consumption categories. Statistical analyses indicate insignificant elasticity coefficients on direct shelter impacts and significant, though smaller, coefficients on indirect ones. As a basic need, shelter 
is relatively more important at low income; in contrast, we expect the importance of nonprimary categories to increase at a higher rate with rising consumer purchasing power.

Our model assigns environmental impacts according to household expenditure on products and services; hence, the model potentially leaves out relevant consumption financed by the government and investment. The implications are twofold. Firstly, potential differences might occur across countries in terms of which goods and services households cover directly, thus, imposing limitations to the comparative analysis. For example, the sector of health and social work services has the second largest carbon footprint out of all industrial sectors in the United States, whereas its lower relative importance in other countries relates to health-related expenditures often being covered by governments or employers (Hertwich 2011; Ferguson and MacLean 2011; Weber and Matthews 2008). Secondly, the model falls short when it comes to endogenizing capital, such as residential buildings and road infrastructure used by household and underestimates household impacts related to shelter and mobility. Actual and imputed rent is included in the calculation of environmental impacts from real estate services, which contributed to $4 \%$ of global carbon and material footprints by households in 2007 .

A significant fraction of household footprints in the developed world depends on impacts embodied in imports from poorer countries. This limits developed countries' ability to decouple impacts from wealth (and expenditure) through technology and efficiency improvements. Our study further has some limitations regarding the macro-level expenditure elasticities. The cross-country regression results need to be interpreted cautiously in the absence of corresponding expenditure elasticities at the micro level (Baiocchi et al. 2010; Hubacek et al. 2014). For example, we have no way of observing potential changes in the expenditure-footprint relationship across countries and socio-economic groups. Furthermore, prior studies have signaled for the benefits of spatial aggregation in relation to the calculation of environmental impacts embodied in trade (Su and Ang 2010). 
Our study provides a comprehensive insight about the environmental consequences of household purchasing decisions, and informs mitigation strategies about the consumption categories with the highest environmental relevance. This work goes beyond presenting a snapshot of household emissions and resource use, and provides a different perspective on footprint determinants and strategies for environmentally-driven reallocation of household spending. Ultimately, a behavioral change may have a significant potential to balance economic growth with environmental performance.

\section{Supporting Information Available}

Information about household environmental footprints including total and per capita absolute values across countries and RoW regions and consumption categories; information about total household expenditure, population and national GDP (PPP); versions of figure 1 and figure 2 depicting all 43 countries; further description of the database.

\section{Acknowledgements}

This work is part of the GLAMURS project financed by the European Union's seventh framework programme (contract 613420). 


\section{References}

Baiocchi, G., J. Minx, and K. Hubacek. 2010. The impact of social factors and consumer behaviour on carbon dioxide emissions in the United Kingdom. Journal of Industrial Ecology 14(1): 50-72. http://doi.wiley.com/10.1111/j.1530-9290.2009.00216.x. Accessed August 19, 2014.

Caeiro, S., T.B. Ramos, and D. Huisingh. 2012. Procedures and criteria to develop and evaluate household sustainable consumption indicators. Journal of Cleaner Production 27: 72-91. http://linkinghub.elsevier.com/retrieve/pii/S0959652611005671. Accessed July 12, 2014.

Davis, S.J. and K. Caldeira. 2010. Consumption-based accounting of CO2 emissions. Proceedings of the National Academy of Sciences of the United States of America 107(12): 5687-5692.

http://www.pubmedcentral.nih.gov/articlerender.fcgi?artid=2851800\&tool=pmcentrez\&r endertype=abstract. Accessed July 15, 2014.

Dietz, T., G.T. Gardner, J. Gilligan, P.C. Stern, and M.P. Vandenbergh. 2009. Household actions can provide a behavioral wedge to rapidly reduce US carbon emissions.

Proceedings of the National Academy of Sciences of the United States of America 106(44): 18452-18456.

http://www.pubmedcentral.nih.gov/articlerender.fcgi?artid=2767367\&tool=pmcentrez\&r endertype $=$ abstract.

EEA. 2001. Indicator Fact Sheet Signals 2001. Chapter Households. http://www.eea.europa.eu/data-and-maps/indicators/household-energyconsumption/household-water-consumption.

EEA. 2013. Environmental pressures from European consumption and production.

Ferguson, T.M. and H.L. MacLean. 2011. Trade-linked Canada-United States household environmental impact analysis of energy use and greenhouse gas emissions. Energy Policy 39(12): 8011-8021.

http://linkinghub.elsevier.com/retrieve/pii/S0301421511007452. Accessed July 31, 2014.

Fischer-Kowalski, M., F. Krausmann, and I. Pallua. 2014. A sociometabolic reading of the Anthropocene: Modes of subsistence, population size and human impact on Earth. The Anthropocene Review 1(1): 8-33. http://anr.sagepub.com/lookup/doi/10.1177/2053019613518033. Accessed November 3, 2014.

Galli, A., T. Wiedmann, E. Ercin, D. Knoblauch, B. Ewing, and S. Giljum. 2012. Integrating Ecological, Carbon and Water footprint into a "Footprint Family" of indicators: Definition and role in tracking human pressure on the planet. Ecological Indicators 16: 100-112. http://www.oneplaneteconomynetwork.org/resources/programmedocuments/WP8_Integrating_Ecological_Carbon_Water_Footprint.pdf. Accessed July $23,2014$. 
Gardner, G.T. and P.C. Stern. 2008. The Short List: The most effective actions US households can take to curb climate change. Environment 50(5): 12-25.

Herendeen, R. and J. Tanaka. 1976. Energy cost of living. Energy I: 165-178.

Hertwich, E.G. 2011. The life cycle environmental impacts of consumption. Economic Systems Research 23(1): 27-47.

http://www.tandfonline.com/doi/abs/10.1080/09535314.2010.536905. Accessed July 16, 2014.

Hertwich, E.G. and G.P. Peters. 2009. Carbon footprint of nations: a global, trade-linked analysis. Environmental Science \& Technology 43(16): 6414-6420.

http://www.ncbi.nlm.nih.gov/pubmed/19746745.

Hoekstra, A.Y. 2003. Virtual water trade: Proceedings of the International Expert Meeting on Virtual Water Trade. http://www.waterfootprint.org/Reports/Report12.pdf.

Hubacek, K., K. Feng, J.C. Minx, S. Pfister, and N. Zhou. 2014. Teleconnecting Consumption to Environmental Impacts at Multiple Spatial Scales. Journal of Industrial Ecology 18(1): 7-9. http://doi.wiley.com/10.1111/jiec.12082. Accessed October 7, 2014.

Huijbregts, M., E. Hertwich, A.H. Strømman, and C. Solli. 2007. Postgraduate School of Industrial Ecology - Life Cycle Assessment. Bratislava, Slovakia.

Kanemoto, K., D. Moran, M. Lenzen, and a. Geschke. 2014. International trade undermines national emission reduction targets: New evidence from air pollution. Global Environmental Change 24: 52-59. http://linkinghub.elsevier.com/retrieve/pii/S095937801300160X. Accessed October 27, 2014.

Kerkhof, A.C., S. Nonhebel, and H.C. Moll. 2009. Relating the environmental impact of consumption to household expenditures: An input-output analysis. Ecological Economics 68(4): 1160-1170.

http://linkinghub.elsevier.com/retrieve/pii/S0921800908003595. Accessed July 12, 2014.

Lee, H. 2008. The combustion-based CO2 emissions data for GTAP Version 7 database.

Lenzen, M., M. Wier, C. Cohen, H. Hayami, S. Pachauri, and R. Schaeffer. 2006. A comparative multivariate analysis of household energy requirements in Australia, Brazil, Denmark, India and Japan. Energy 31: 181-207. http://linkinghub.elsevier.com/retrieve/pii/S0360544205000113. Accessed October 11, 2014.

Munksgaard, J. and K.A. Pedersen. 2001. CO2 accounts for open economies: Producer or consumer responsibility? Energy Policy 29: 327-334.

http://linkinghub.elsevier.com/retrieve/pii/S0301421500001208.

Peters, G. and E. Hertwich. 2008. CO2 embodied in international trade with implications for global climate policy. Environmental Science \& Technology 42(5): 1401-1407. 
Peters, G.P. and E.G. Hertwich. 2006. The importance of imports for household environmental impacts. Journal of Industrial Ecology 10(3): 89-109.

http://doi.wiley.com/10.1162/jiec.2006.10.3.89.

Peters, G.P., J.C. Minx, C.L. Weber, and O. Edenhofer. 2011. Growth in emission transfers via international trade from 1990 to 2008. Proceedings of the National Academy of Sciences of the United States of America 108(21): 8903-8908.

http://www.pubmedcentral.nih.gov/articlerender.fcgi?artid=3102371\&tool=pmcentrez\&r endertype $=$ abstract. Accessed October 18, 2014.

SNA. 2008. System of National Accounts.

http://unstats.un.org/unsd/nationalaccount/docs/SNA2008.pdf.

Stadler, K., K. Steen-Olsen, and R. Wood. 2014. The "Rest of the World" - Estimating the economic structure of missing regions in global multi-regional input-output tables. Economic Systems Research 26(3): 303-326.

http://www.tandfonline.com/doi/abs/10.1080/09535314.2014.936831. Accessed March $11,2015$.

Steen-Olsen, K., J. Weinzettel, G. Cranston, a E. Ercin, and E.G. Hertwich. 2012. Carbon, Land, and Water Footprint accounts for the European Union: Consumption, production, and displacements through international trade. Environmental Science \& Technology 46(20): 10883-10891. http://www.ncbi.nlm.nih.gov/pubmed/23013466.

Steen-Olsen, K., R. Wood, and E.G. Hertwich. 2014. The Carbon Footprint of Norwegian household consumption 1999-2012.

Su, B. and B.W. Ang. 2010. Input-output analysis of CO2 emissions embodied in trade: The effects of spatial aggregation. Ecological Economics 70(1): 10-18. http://linkinghub.elsevier.com/retrieve/pii/S092180091000340X. Accessed March 6, 2015.

Tukker, A., T. Bulavskaya, S. Giljum, A. De Koning, S. Lutter, M. Simas, K. Stadler, and R. Wood. 2014. The global resource footprint of nations: Carbon, water, land and materials embodied in trade and final consumption.

http://creea.eu/index.php/documents2/cat_view/16-creea-booklet.

Tukker, A., M.J. Cohen, K. Hubacek, and O. Mont. 2010. The impacts of household consumption and options for change. Journal of Industrial Ecology 14(1): 13-30. http://doi.wiley.com/10.1111/j.1530-9290.2009.00208.x. Accessed July 23, 2014.

Tukker, A. and B. Jansen. 2006. Environmental impacts of products: A detailed review of studies. Journal of Industrial Ecology 10(3): 159-182.

http://doi.wiley.com/10.1162/jiec.2006.10.3.159.

Tukker, A., A. de Koning, R. Wood, T. Hawkins, S. Lutter, J. Acosta, J.M. Rueda Cantuche, and colleagues. 2013. EXIOPOL - Development and illustrative analyses of a detailed global MR EE SUT/IOT. Economic Systems Research 25(1): 50-70.

http://www.tandfonline.com/doi/abs/10.1080/09535314.2012.761952. Accessed July 13, 2014. 
Vewin. 2012. Dutch drinking water statistics.

http://www.vewin.nl/SiteCollectionDocuments/Publicaties/English _publications/Vewin_Dutch_Drinking_water_statistics_2012.pdf.

Vickers, A. 2001. Handbook of water use and conservation. Handbook of Water U. Waterplow Press.

Wackernagel, M. and W. Rees. 1996. Our Ecological Footprint: Reducing human impact on the Earth. Canada: New Society Publishers.

Weber, C.L. and H.S. Matthews. 2008. Quantifying the global and distributional aspects of American household carbon footprint. Ecological Economics 66(2-3): 379-391. http://linkinghub.elsevier.com/retrieve/pii/S0921800907004934. Accessed July 16, 2014.

Weinzettel, J., E.G. Hertwich, G.P. Peters, K. Steen-Olsen, and A. Galli. 2013. Affluence drives the global displacement of land use. Global Environmental Change 23(2): 433438. http://linkinghub.elsevier.com/retrieve/pii/S0959378012001501. Accessed July 10, 2014.

Wiedmann, T. and J. Minx. 2008. A definition of “ Carbon Footprint .” In Ecological Economics Research Trends: Chapter 1, 1-11. Nova Science Publishers. http://www.censa.org.uk/docs/ISA-UK_Report_07-01_carbon_footprint.pdf.

Wiedmann, T., R. Wood, J.C. Minx, M. Lenzen, D. Guan, and R. Harris. 2010. A Carbon Footprint time series of the UK - Results from a multi-region input-output model. Economic Systems Research 22(1): 19-42. http://www.tandfonline.com/doi/abs/10.1080/09535311003612591. Accessed July 13, 2014.

Wiedmann, T.O., H. Schandl, M. Lenzen, D. Moran, S. Suh, J. West, and K. Kanemoto. 2013. The material footprint of nations. Proceedings of the National Academy of Sciences of the United States of America: 1-6. http://www.ncbi.nlm.nih.gov/pubmed/24003158. Accessed July 10, 2014.

Wood, R., K. Stadler, T. Bulavskaya, S. Lutter, S. Giljum, A. de Koning, J. Kuenen, and colleagues. 2015. Global sustainability accounting - developing EXIOBASE for multiregional footprint analysis. Sustainability 7(1): 138 - 163.

Wyckoff, A.W. and J.M. Roop. 1994. The embodiment of carbon in imports of manufactured products: Implications for international agreements on greenhouse gas emissions. Energy Policy 22(3): 187-194. 


\section{$<$ heading level 1 $>$ About the Authors}

Diana Ivanova is a PhD Candidate at the Industrial Ecology Programme at the Norwegian University of Science and Technology (NTNU) in Trondheim, Norway.

Konstantin Stadler is a senior researcher at the Industrial Ecology Programme at the Norwegian University of Science and Technology (NTNU) in Trondheim, Norway.

Kjartan Steen-Olsen is a researcher at the Industrial Ecology Programme at the Norwegian University of Science and Technology (NTNU) in Trondheim, Norway.

Richard Wood is a senior researcher at the Industrial Ecology Programme at the Norwegian University of Science and Technology (NTNU) in Trondheim, Norway.

Gibran Vita is a researcher at the Industrial Ecology Programme at the Norwegian University of Science and Technology (NTNU) in Trondheim, Norway.

Edgar Hertwich is the director of the Industrial Ecology Programme and a Professor at the Department of Energy and Process Engineering at the Norwegian University of Science and Technology (NTNU) in Trondheim, Norway. 